Diabetologia 11, 541-548 (1975)

(C) by Springer-Verlag 1975

\title{
Radioimmunological Determination of Human C-Peptide in Serum
}

\author{
L. G. Heding \\ Novo Research Institute, Copenhagen, Denmark \\ Received: February 20, 1975, and in revised form: August 18, 1975
}

\begin{abstract}
Summary. A routine radioimmunoassay for human C-peptide in serum is described. Antibodies against human C-peptide were raised by immunizing guinea pigs with human $b$-component. Nine out of 12 animals produced useful antibodies within 6 months. Insulin antibodies coupled to Sepharose were used to bind human proinsulin and insulin in the serum and after centrifugation C-peptide was determined in the supernatant. The detection limit of the assay (calculated as 2 SD from zero) was about 0.003 pmole of C-peptide (in $100 \mu \mathrm{l}$ ). The main sources of error were: (1) Normal and diabetic sera devoid of C-peptide gave a displacement of ${ }^{125} \mathrm{I}$-Tyr-C-peptide varying from 0 to $0.16 \mathrm{nM}$ ( 6 different antisera). Only one antiserum (M 1181) showed no displacement, and the values of C-peptide determined with this antiserum in normal and diabetic sera were lower than the values determined with another antiserum, which gave a value of $0.07 \mathrm{nM}$ in the sera free of C-peptide. It is suggested
\end{abstract}

that displacement found with most antisera is due to substances in serum that are not related to C-peptide or proinsulin. (2) Serial dilutions of pancreatic extracts and sera may yield dilution curves slightly different to those of the synthetic standard. Possible explanations are discussed. These sources of error can be eliminated or reduced by the proper selection of antisera. Fasting sera from 15 normals, 8 maturity-onset diabetics and 10 insulin-requiring diabetics showed the following concentrations of C-peptide: (M 1181) $0.35 \pm 0.09,0.74 \pm 0.51$ and $0.21 \pm 0.14(\mathrm{nM}$, mean $\pm \mathrm{SD})$. One hour after $1.75 \mathrm{~g} / \mathrm{kg}$ oral glucose the values increased to $2.24 \pm$ $0.71,2.34 \pm 1.18$ and $0.42 \pm 0.24 \mathrm{nM}$.

Key words: Radioimmunoassay, human C-peptide, human proinsulin, insulin.
A sensitive and specific immunoassay for routine determination of human $\mathrm{C}$-peptide in serum requires a high-affinity antibody and a simple and quick method for the separation of C-peptide from proinsulin. Unfortunately, C-peptides (molecular weight about 3000 ) show low immunogenicity [10] in spite of the great difference in the amino acid sequences of the injected material and of the endogenous C-peptide of the immunized animal. An assay of human C-peptide in serum has been described [14] that comprised extraction of serum, gel filtration of the serum extract and analysis of the individual fractions after evaporation, using an antiserum raised against the natural human C-peptide coupled to albumin. Recently, total C-peptide (CPR) immunoreactivity (C-peptide + proinsulin + intermediates) were determined in unextracted serum [2]. This method, in contrast to [14], yielded higher molar concentrations of C-peptide than those of insulin. This was in agreement with the findings in ox serum [16] and in human sera [6]. An assay based upon antibodies against synthetic human connecting peptide has also been described [8]. As a consequence of its low immunogenicity, antibodies to human C-peptide show low affinity, which implies a high detection limit, and the best result yet reported was the recording of $0.05 \mathrm{ng}$ per tube, corresponding to about $0.25 \mathrm{ng} / \mathrm{ml}$ sample [8]. A method has been reported [6] of raising antibodies of high affinity to human C-peptide, using human b-component for immunization and a quick method of separation of $\mathrm{C}$ peptide from proinsulin + intermediates (henceforth referred to as PLI). The present paper describes a new and simplified method of separation of proinsulin + insulin + intermediates from C-peptide, using antibodies against pork insulin coupled to Sepharose. The advantage of this separation over the separation techniques formerly described is that, besides being easier and simpler, this technique enables one to isolate proinsulin from, e.g., $2 \mathrm{ml}$ of serum.

\section{Materials and Methods}

\section{Preparation and Testing of Antibodies to Human C-Peptide}

Human C-peptide was prepared according to [9] and tyrosylated and iodinated as described in [6]. Twelve guinea pigs were immunized with $1 \mathrm{ml}$ of an emulsion consisting of equal volumes of Freund's adjuvant (complete in the first injection, incomplete in subsequent injections) and a solution of crude human b-component $(2 \mathrm{mg} / \mathrm{ml})$ obtained by gel filtration of first crystals of human insulin on Sephadex G 50. The animals were injected every third week. Blood was drawn by cardiac puncture, initially 14 days after the 
fourth injection, then regularly 14 days after each subsequent injection. Human ${ }^{125} \mathrm{I}$-Tyr-C-peptide and antisera were diluted in phosphate buffer $(0.04 \mathrm{M}, \mathrm{pH}$ 7.4) containing human albumin (Behringwerke, electrophoretic purity $100 \%)(1 \mathrm{~g} / \mathrm{l})$ and thiomersal $(0.2 \mathrm{~g} / \mathrm{l})$, henceforth referred to as FAM. All standards and samples were diluted in phosphate buffer (0.04 M, pH 8.4) containing $\mathrm{NaCl}(6 \mathrm{~g} / \mathrm{l})$, human albumin $(60 \mathrm{~g} / 1)$ and thiomersal $(0.2 \mathrm{~g} / \mathrm{l})$ (NaFAM). The antisera were tested in the following manner: to duplicated of $100 \mu \mathrm{l}$ of diluted serum were added 100 $\mu \mathrm{l}$ of ${ }^{125} \mathrm{I}$-Tyr-C-peptide $(2 \mathrm{ng} / \mathrm{ml})$ and $100 \mu \mathrm{l}$ of NaFAM. After $20-24 \mathrm{hrs}$ of incubation at $4^{\circ} \mathrm{C}$, free and antibody-bound ${ }^{125} \mathrm{I}$-Tyr-C-peptide was separated by addition of $1.6 \mathrm{ml} \mathrm{95 \% (v/v)} \mathrm{ethanol} \mathrm{at} 4^{\circ} \mathrm{C}$. After centrifugation and one wash the precipitate was dissolved in $0.6 \mathrm{ml}$ of $0.05 \mathrm{~N} \mathrm{NaOH}$ and counted as described for glucagon [5].

\section{Preparation and Testing of Insulin Coupled to Sepha- rose $(S-I)$}

Monocomponent (MC) insulin (ox or pork) was coupled to Sepharose as follows: $50 \mathrm{~g}$ of Sepharose 4 B slurry was suspended in $10 \mathrm{ml}$ of distilled water. $10 \mathrm{~g}$ of $\mathrm{CNBr}$ was added to the suspension and the $\mathrm{pH}$ maintained at 10.5 for 15 min with $4 \mathrm{~N} \mathrm{NaOH}$. The activated Sepharose was filtered off and washed with 0.51 of $0.2 \mathrm{M} \mathrm{NaHCO}_{3}$, and then sucked dry. The $\mathrm{CNBr}$-activated Sepharose $4 \mathrm{~B}$ was then suspended in a solution of $\mathrm{MC}$ insulin prepared as follows: $2 \mathrm{~g}$ of insulin was dissolved in $100 \mathrm{ml}$ of distilled water acidified by addition of $1 \mathrm{~N} \mathrm{HCl}$ to a $\mathrm{pH}$ of approximately 2.5. $100 \mathrm{mg}$ of $\mathrm{Na}_{2}$ EDTA was added and the $\mathrm{pH}$ raised to approximately 7 with $1 \mathrm{~N} \mathrm{NaOH}$. The insulin solution was mixed with $100 \mathrm{ml}$ of $0.2 \mathrm{M} \mathrm{NaHCO}_{3}, \mathrm{pH}$ 8.0 , and the $\mathrm{pH}$ adjusted to 8.0. The reaction mixture of activated Sepharose and insulin solution was stirred at $4^{\circ} \mathrm{C}$ overnight. Absorbance at 278 and $250 \mathrm{~nm}$ was measured before and 1,3 and $20 \mathrm{~h}$ after the start of reaction. About $20 \%$ of the insulin was found to be bound to the Sepharose after $1 \mathrm{~h}$, whereas no further increase in binding was found between 1 and $20 \mathrm{~h}$. After binding of the insulin to Sepharose, $50 \mathrm{ml}$ of $5 \mathrm{M}$ redistilled ethanolamine adjusted to $\mathrm{pH} 8.1$ with conc. $\mathrm{HCl}$ was added to the suspension in order to inactivate the residual reactive groups on the activated Sepharose. After $64 \mathrm{~h}$ of stirring at $4^{\circ} \mathrm{C}$, the Sepharose was filtered off and washed with 0.5 l each of the following solutions: distilled $\mathrm{H}_{2} \mathrm{O}, 0.5 \mathrm{M} \mathrm{NaCl}$ in $60 \%$ ethanol, and NaFAM. Finally, the Sepharose with insulin coupled to it (in the following referred to as S-I) was sucked dry and suspended in NaFAM, $\mathrm{pH} 7.4$, to a concentration of $1 \mathrm{mg}$ bound insulin per $\mathrm{ml}$.
The immunoreactive insulin (IRI) of the S-I was determined as follows: To duplicated of $100 \mu \mathrm{l}$ of S-I suspension were added increasing amounts of guinea pig antiinsulin serum with known binding capacity. After $20 \mathrm{~h}$ at $4^{\circ} \mathrm{C}$ with shaking, the $\mathrm{S}$-I was removed by centrifugation and the insulin binding capacity determined in the supernatant, using ${ }^{125} \mathrm{I}$-pork insulin. The insulin antibodies bound by the S-I were calculated and referred to as the IRI of the S-I.

\section{Preparation of Antibodies to Insulin, Coupling to Se- pharose ( $S$-AIS) and Binding Capacity of S-AIS}

Antibodies to insulin were isolated as follows: guinea pig antipork insulin serum was prepared by repeated immunization as described in [4]. Guinea pig serum with a known insulin-binding capacity (in the range of 4 to 20 units) was mixed with a suspension of S-I containing a surplus of IRI ( $8-40$ units). The mixture was shaken overnight at $4^{\circ} \mathrm{C}$, filtered in a small glass tube containing glass paper, and washed three times with $1 \mathrm{ml} 0.6 \% \mathrm{NaCl}$. The insulin antibodies were eluted from the $\mathrm{S}-\mathrm{I}$ column with $2 \mathrm{ml}$ portions of dilute $\mathrm{HCl}(0.005-0.001 \mathrm{~N})$ at $0^{\circ} \mathrm{C}$. The 2 ml eluates were run direct into tubes containing $2 \mathrm{ml} 0.04 \mathrm{M}$ phosphate buffer (NaFAM) to reduce the time of exposure of the antibodies to a low $\mathrm{pH}$. The antibodycontaining eluates were pooled, freeze-dried and stored at $-18^{\circ} \mathrm{C}$ until used.

The purified insulin antibodies were coupled to CNBr-activated Sepharose $4 \mathrm{~B}$ in the following manner: the freeze-dried antibodies were dissolved in 25 $\mathrm{ml}$ of distilled water to a concentration of approximately $0.5 \mathrm{unit} / \mathrm{ml}$ (calculated: $0.48 \mathrm{U} / \mathrm{ml}$; checked by analysis: $0.51 \mathrm{U} / \mathrm{ml}$ ), $400 \mathrm{mg}$ of $\mathrm{NaHCO}_{3}$ and $200 \mathrm{mg}$ of $\mathrm{NaCl}$ were added and the $\mathrm{pH}$ adjusted to 8.0. The solution was turbid. A quantity of freshly prepared CNBr-activated Sepharose $4 \mathrm{~B}$ corresponding to $24 \mathrm{~g}$ Sepharose was suspended in the antibody solution and the reaction mixture allowed to stand at $4^{\circ} \mathrm{Covernight}$ with stirring. $24 \mathrm{ml}$ of redistilled ethanolamine adjusted to a $\mathrm{pH}$ of 8.0 with conc. $\mathrm{HCl}$ was added, the mixture stirred at $4^{\circ} \mathrm{C}$ for $24 \mathrm{hrs}$ and its preparation completed as described in regard to S-I above. In the following, the Sepharose-bound insulin antibodies are referred to as S-AIS.

The binding capacity of the S-AIS was determined by adding increasing amounts of ${ }^{125} \mathrm{I}$ pork insulin, ${ }^{125} \mathrm{I}$ pork proinsulin or ${ }^{125} \mathrm{I}$ ox proinsulin, shaking overnight at $4^{\circ} \mathrm{C}$, centrifuging, washing and counting the precipitate. Based on its estimated capacity to bind ${ }^{125}$ I pork insulin, an S-AIS suspension capable of binding $0.1 \mathrm{U} / \mathrm{ml}$ was prepared in NaFAM and stored in 1 $\mathrm{ml}$ portions at $-18^{\circ} \mathrm{C}$ until use. 


\section{Removal of Proinsulin + Insulin}

Proinsulin + insulin in serum samples or pancreas extracts was bound to S-AIS in the following manner: To $1 \mathrm{ml}$ of serum was added $100 \mu \mathrm{l}$ of an S-AIS suspension with a binding capacity of $0.01 \mathrm{U} / \mathrm{ml}$. The serum samples were shaken overnight at $4^{\circ} \mathrm{C}$, centrifuged, and C-peptide determined in the supernatant.

\section{Immunoassay Procedure}

To triplicates $100 \mu \mathrm{l}$ volumes of standard solutions containing 0.05-1.0 pmole human synthetic $\mathrm{C}$ peptide (a gift from Dr. K. Naithani, Wollforschungsinstitut, Aachen, West Germany) per ml was added $100 \mu \mathrm{l}$ of dilute antiserum, e.g., M 1017 diluted $1: 800$. The mixture was incubated at $4^{\circ} \mathrm{C}$ for 24 hours, $100 \mu 1$ of ${ }^{125} \mathrm{I}$-Tyr-C-peptide $(0.67 \mathrm{nM})$ was added, the $4^{\circ} \mathrm{C}-24-\mathrm{h}$ incubation repeated and the antibody-bound C-peptide separated using $1.6 \mathrm{ml}$ $95 \%$ ethanol, was described for glucagon [5].

\section{Results}

\section{Production of Antibodies against Human C-Peptide and Their Use in Preparing Standard Curves}

Nine out of the twelve guinea pigs developed antibodies to C-peptide that could be used for immunoassay in final dilutions of $1: 1500$ or higher. Fig. 1 shows the standard curves of M $1017(1: 2400)$ after 6 months, M 1181 (1:3000) after 8 months, M 1183 $(1: 1800)$ after 6 months and M $1187(1: 3000)$ after 6 months of immunization - final dilutions in parentheses. The nonspecific coprecipitation (absence of antibodies) by ethanol was in the range of $1-3 \%$ of the ${ }^{125}$ I-Tyr-C-peptide; a surplus of antibodies bound $72-66 \%$ of the tracer. However, with a recently improved quality of the tracer, $80 \%$ binding was found [12].

\section{Incubation Time and Temperature}

A study of the rate of reaction at $4^{\circ} \mathrm{C}$ between ${ }^{125}$ I-Tyr-C-peptide and M 1017 showed that it was necessary to incubate for over 10 hours to reach a plateau, and for practical reasons incubations were run overnight.

When ${ }^{125}$ I-Tyr-C-peptide was incubated with dilute M 1017 at 4 and $25^{\circ} \mathrm{C}$ for 24 hrs (10 tubes at each temperature) the mean binding percentages were 28.4 \pm 0.38 and $23.3 \pm 0.30$, respectively (mean of $10 \pm 1$ SD). Thus the equilibrium constant appears to be

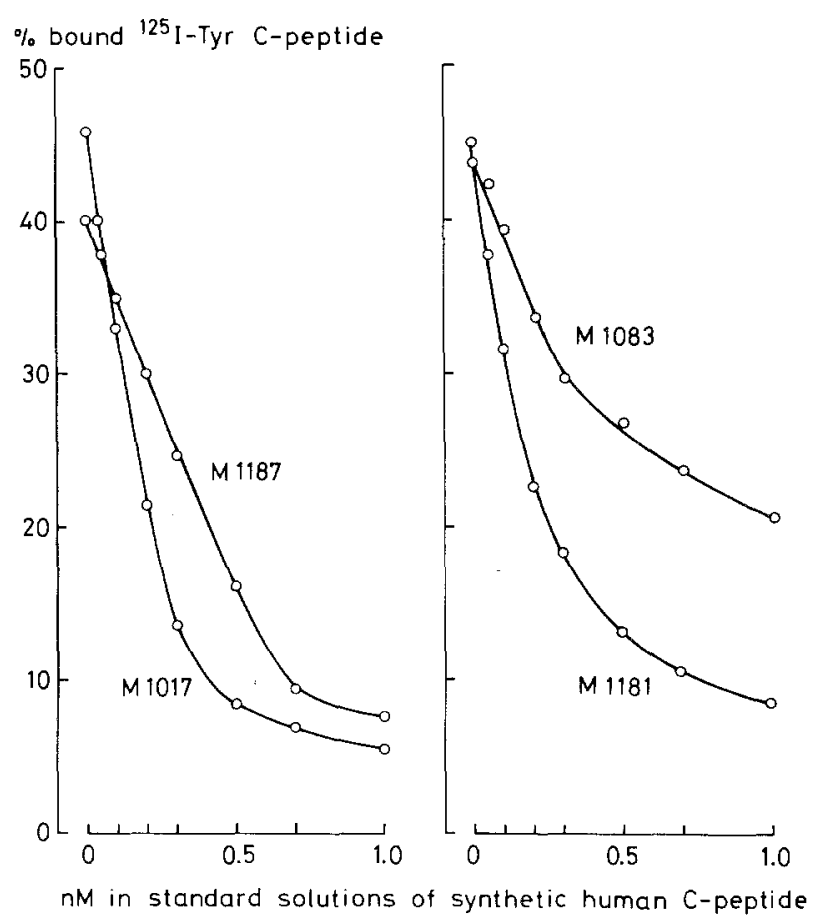

Fig. 1. Standard curves obtained with four different anti-human-bcomponent guinea pig sera: M $1017(1: 2400)$, M $1187(1: 3000)$, M $1083(1: 1800)$ and $M 1181(1: 3000)$. The final dilution is shown in brackets

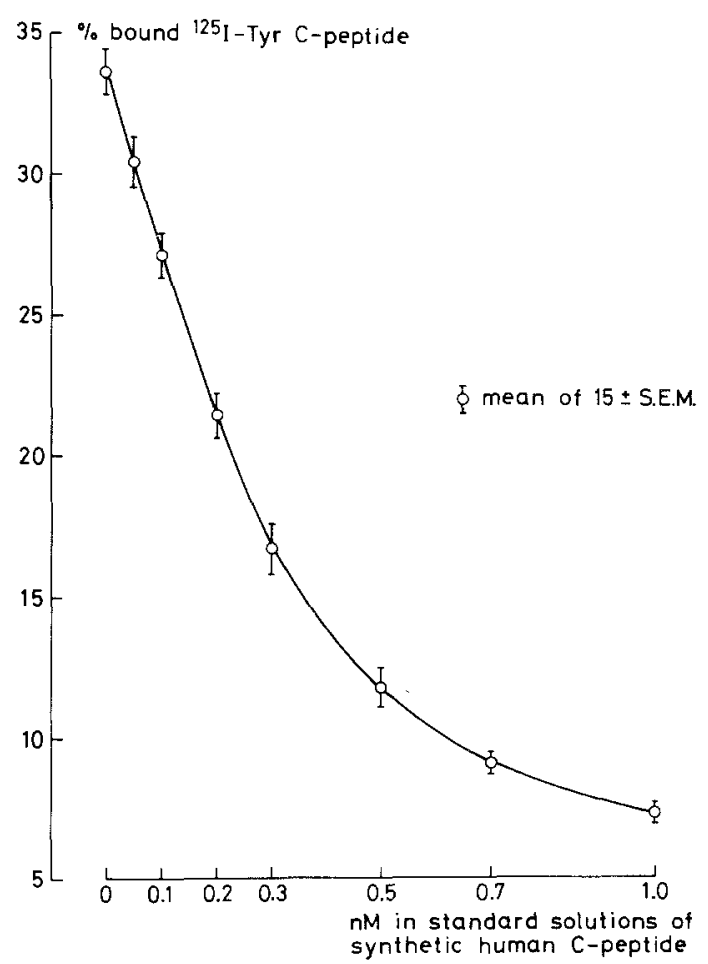

Fig. 2. Reproducibility of the standard curve, using M 1017 
higher at $4^{\circ} \mathrm{C}$ than at $24^{\circ} \mathrm{C}$, and all incubations were run at $4^{\circ} \mathrm{C},{ }^{125} \mathrm{I}-\mathrm{Tyr}-\mathrm{C}$-peptide was added at $4^{\circ} \mathrm{C}$, and in the final step the ethanol, too, was added at $4^{\circ} \mathrm{C}$.

\section{Reproducibility of the Standard Curve, Detection Limit and Sensitivity}

Fig. 2 shows the reproducibility of the standard curve obtained with M 1017 over a period of 7 months, using 3 different batches of ${ }^{125}$ I-Tyr-C-peptide. Sera from two juvenile diabetics who had been insulin treated for several years, both of whom showed a complete absence of B-cell activity in response to 1 $\mathrm{mg}$ of glucagon i.v. [13], were analyzed with 6 of the antisera. The values were between 0 and $0.16 \mathrm{nM}$. Only one serum, M 1181, gave values not significantly different from zero, while M 1017 gave $0.03-0.07$ $\mathrm{nM}$. The detection limit for M 1181 and M 1017 defined as the smallest quantity of C-peptide that can be distinguished as significantly different from zero point ( $=2 \mathrm{SD}$ ) - was slightly below $0.03 \mathrm{nM}$ or 0.003 pmole in $100 \mu \mathrm{l}$. However, since serum contains substances that do react with some antisera, the true detection limit is higher, except for M 1181. Thus only values higher than $0.07 \mathrm{pmole} / \mathrm{ml}$ should be regarded as positive with $\mathrm{M}$ 1017. Three standard sera were subjected to repeated assays using both $\mathrm{M} 1017$ and $\mathrm{M}$ 1181. The mean values \pm 1 SD were: $M$ 1017: (A) $0.58 \pm 0.12$ (13), (B) $0.91 \pm 0.11$ (30), (C) $3.53 \pm$ 0.37 (11); and M 1181: (A) $0.45 \pm 0.03$ (18), (B) 0.72 \pm 0.03 (19), (C) $3.27 \pm 0.11$ (19). The figures in parentheses are the number of assays run with the sera.
In the range of $0-0.3 \mathrm{nM}$, the decrease in $\%$ bound tracer was about 17 (later improved to approximately $30 \%$, see Fig. 1), corresponding to $5.6 \%$ per $0.1 \mathrm{nM}$. As the mean standard deviation of 115 triplicates was 1.87 (relative) per cent, or about 0.6 absolute per cent, the sensitivity defined as 2 standard deviations in the aforementioned range was about 0.0025 pmole in $100 \mu \mathrm{l}$ for both M 1017 and M 1181.

Preparation of Insulin Antibodies Coupled to Sepharose (S-AIS), Yield and Capacity to Bind Insulin and Proinsulin

The insulins coupled to Sepharose, $S-\mathrm{I}_{\text {ox }}$ and $\mathrm{S}-\mathrm{I}_{\text {pork }}$, were suspended in phosphate buffer to a calculated concentration of $1 \mathrm{mg}$ bound insulin/ml (based on absorbance). The IRI was estimated to be 4.0-4.9 $\mathrm{U} / \mathrm{ml}$ for the $\mathrm{S}-\mathrm{I}_{\mathrm{ox}}$, and $3.8-4.1 \mathrm{U} / \mathrm{ml}$ for $\mathrm{S}-\mathrm{I}_{\text {pork }}$, meaning that about $20 \%$ of the bound insulin exhibited immunoreactivity.

Insulin antibodies were bound to $S-\mathrm{I}_{\text {pork }}$ at neutral $\mathrm{pH}$ and eluted, after 3 washes, with dilute $\mathrm{HCl}$. More than $95 \%$ of the antibodies were bound to S-I and the yield of antibodies in the acid eluates was in the range of $25-37 \%$. The coupling procedure was effective, analyses showing that more than $95 \%$ of the antibodies had been bound to Sepharose. Table 1 shows the binding capacity of the S-AIS towards ${ }^{125} \mathrm{I}$-pork insulin and ${ }^{125}$ I-pork and ox proinsulin (about 750 pmoles/ $\mathrm{ml}$ ). Apparently the S-AIS had less affinity to the proinsulin, since a higher surplus of ${ }^{125}$ I proinsulin was necessary to occupy all the binding sites as compared to insulin.

Table 1. Binding capacity of S-AIS toward ${ }^{125}$ I pork insulin, ${ }^{125}$ I pork proinsulin and ${ }^{125}$ I ox proinsulin

\begin{tabular}{|c|c|c|c|c|c|}
\hline $\begin{array}{l}\text { added } \\
{ }^{125} \text { I insulin } \\
\text { pmoles }\end{array}$ & $\begin{array}{l}\text { bound } \\
{ }^{125} I \text { insulin } \\
\text { per } 50 \mu \mathrm{I} \\
\text { S-AIS susp. } \\
(1: 10) \\
\text { pmoles }\end{array}$ & $\begin{array}{l}\text { added }{ }^{125} \text { I pork } \\
\text { proinsulin }\end{array}$ & $\begin{array}{l}\text { bound }{ }^{125} \text { I pork } \\
\text { proinsulin } \\
\text { per } 50 \mu 1 \\
\text { S-AIS susp. } \\
(1: 10) \\
\text { pmoles }\end{array}$ & $\begin{array}{l}\text { added }{ }^{125} \text { I ox } \\
\text { proinsulin }\end{array}$ & $\begin{array}{l}\text { bound }{ }^{125} I \text { ox } \\
\text { proinsulin } \\
\text { per } 50 \mu 1 \\
\text { S-AIS suspension } \\
(1: 10) \\
\text { pmoles }\end{array}$ \\
\hline 8.4 & 3.3 & 4.6 & $2.7^{\mathrm{a}}$ & 4.6 & $2.3^{\mathrm{a}}$ \\
\hline 12.6 & 3.8 & 6.9 & $3.1^{\mathrm{a}}$ & 6.9 & $2.8^{\mathrm{a}}$ \\
\hline 16.8 & 3.6 & 9.4 & 3.6 & 9.4 & $3.2^{\mathrm{a}}$ \\
\hline 21.0 & 3.4 & 11.7 & 3.5 & 11.7 & 3.9 \\
\hline 25.2 & 3.7 & 14.1 & 3.9 & 14.1 & 3.9 \\
\hline 29.4 & 3.8 & 16.4 & 3.8 & 16.4 & 3.9 \\
\hline 33.8 & 3.3 & 18.7 & 3.9 & 18.7 & 4.1 \\
\hline mean $\pm 1 \mathrm{SD}$ & \multicolumn{2}{|l|}{$3.56 \pm 0.22$} & \multicolumn{2}{|l|}{$3.74 \pm 0.18$} & $3.95 \pm 0.10$ \\
\hline $\mathrm{pmole} / \mathrm{ml}$ & \multicolumn{2}{|c|}{$712(\sim 0.1 \mathrm{U} / \mathrm{ml})$} & 748 & & 790 \\
\hline
\end{tabular}

a not included in the calculation of the mean value 
Table 2. Determination of human C-peptide in a waste product of human insulin production, pmole/ml $x$ dilution. M 1017

\begin{tabular}{llll}
\hline Dilution & Batch 1 & Batch 2 & Batch 3 \\
\hline $1: 4000$ & 1520 & 1680 & 1480 \\
$1: 6000$ & 1920 & 2100 & 1920 \\
$1: 8000$ & 2160 & 2400 & 2080 \\
$1: 10000$ & 2300 & 2400 & 2000 \\
\hline
\end{tabular}

In the routine separation of insulin + proinsulin from C-peptide, the amount of S-AIS has to be adequate to bind all the insulin sites. $100 \mu 1$ of an S-AIS suspension with a binding capacity of $0.01 \mathrm{U} / \mathrm{ml}$ bound about $95 \%$ of up to $10 \mathrm{ng}$ of either ${ }^{125} \mathrm{I}$ ox proinsulin, ${ }^{125} \mathrm{I}$ pork proinsulin or ${ }^{125} \mathrm{I}$ pork insulin. When use was made of solutions of unlabelled human insulin, pork proinsulin and ox proinsulin, similar results were recorded with up to $10 \mathrm{ng} / \mathrm{ml}$, inasmuch as about $95 \%$ of the immunoreactivity was removed from $1 \mathrm{ml}$ using $100 \mu \mathrm{l} \mathrm{S}$-AIS $(0.01 \mathrm{U} / \mathrm{ml})$. Binding of human proinsulin to S-AIS was also established employing quantities of 3 and $5 \mathrm{ng} / \mathrm{ml} \mathrm{(10} \mathrm{ng} \mathrm{was} \mathrm{not}$ available).

\section{Assay of Pancreatic Extracts Containing C-Peptide}

Three batches of mother liquor from the salting-out process $(15 \% \mathrm{NaCl})$ in the pilot-plant-scale preparation of human insulin were analyzed with a view to comparing the immunoreactivity of the natural $\mathrm{C}$ peptide (or C-peptide-like components) with the synthetic standard, since no purified natural C-peptide was available. From Table 2 it appears that the natural C-peptide consistently showed a dilution pattern slightly different to that of the synthetic standard.

\section{Determination of C-peptide in Serum}

Table 3 shows the effect of diluting samples from normal persons with high $(>1 \mathrm{pmole} / \mathrm{ml}) \mathrm{C}$-peptide concentrations using M 1017. In most sera a dilution effect was observed, i.e. higher values were recorded with higher dilutions, as in the case of the pancreatic extracts. With M 1181 the dilution effect was less pronounced.

Table 4 shows the corresponding IRI and C-peptide values measured in 15 normal persons, 8 maturityonset diabetics and 10 insulin requiring diabetics. None of the diabetics had ever been treated with insulin and therefore had no insulin antibodies. Cpeptide was estimated with M 1017 and M 1181.

\section{Discussion}

\section{Antibody Production, Incubation Time and Tempera- ture}

It was possible to obtain antibodies to human C-peptide in 9 of 12 guinea pigs immunized with human $\mathrm{b}$ component. There is no means of comparing this result with other methods used to produce antibodies because there is no indication of the number of positive animals in the relevant publications $[2,8,14]$. However, the technique is still far from satisfactory and other methods, including the coupling of C-peptide, should be investigated when sufficient material becomes available.

The reaction between ${ }^{125} \mathrm{I}$-Tyr-C-peptide and the antisera had to be carried out at $4^{\circ} \mathrm{C}$ in order to obtain the maximum of binding and the incubation period had to be extended to over 10 hours.

\section{Preparation of $S-I$ and $S-A I S$ and Their Immunologi- cal Activities}

The IRI of the insulin covalently bound to Sepharose was about $20 \%$. This probably means that $80 \%$ of the insulin is attached to the Sepharose in such a way as to make the immunogenic sites inaccessible to the antibodies. Nevertheless, the S-I is capable of binding

Table 3. C-peptide determined at different dilution ratios in serum samples from normal persons after oral glucose. Concentration in diluted sample x dilution factor, $n M$. Antiserum: $M 1017$

\begin{tabular}{|c|c|c|c|c|c|c|c|c|c|c|c|c|c|c|c|c|c|c|c|c|}
\hline \multicolumn{21}{|c|}{ s a mple No. } \\
\hline Dilution & A & B & $\mathrm{C}$ & $\mathrm{D}$ & $\mathrm{E}$ & $\mathrm{F}$ & $\mathrm{G}$ & $\mathrm{H}$ & I & $\mathrm{J}$ & $\mathrm{K}$ & $\mathrm{L}$ & M & $\mathrm{N}$ & 0 & $\mathrm{P}$ & $\mathrm{Q}$ & $\mathrm{R}$ & $S$ & $\mathrm{~T}$ \\
\hline $1: 2$ & 2.0 & 2.3 & 1.9 & 2.0 & 2.0 & 2.0 & & & & & & & & & & & & & & \\
\hline $1: 4$ & 2.0 & 2.2 & 1.9 & 2.0 & 2.0 & 1.9 & 2.8 & 2.2 & 1.9 & 1.7 & & & & & & & & & & \\
\hline $1: 5$ & & & & & & & & & & & 1.05 & 2.05 & 2.60 & 2.0 & 4.2 & 2.9 & 3.7 & 3.4 & 4.8 & \\
\hline $1: 6$ & 2.2 & 2.2 & 1.9 & 2.3 & 2.3 & 1.9 & - & & & & & & & & & & & & & \\
\hline $1: 8$ & 2.3 & 2.0 & 1.8 & 2.4 & 1.3 & 1.7 & 2.6 & 2.4 & 1.8 & 1.7 & & & & & & & & & & 3.9 \\
\hline $1: 10$ & 2.6 & 2.3 & 2.3 & 2.8 & 2.3 & 2.1 & & & & & 1.20 & 2.30 & 3.20 & 2.2 & 4.2 & 3.6 & 3.7 & 3.8 & & 4.3 \\
\hline $1: 20$ & & & & & & & & & & & & & 4.0 & & & & & & 5.2 & 4.0 \\
\hline
\end{tabular}


Table 4. IRI and C-peptide in normal subjects, maturity-onset diabetics and insulin-requiring diabetics, fasting and $1 \mathrm{~h}$ after 1.75 goral glucose/ $\mathrm{kg}$, in $n M$ (mean $\pm 1 \mathrm{SD})$. C-peptide determined with M 1017 and M 1181

\begin{tabular}{|c|c|c|c|c|c|c|c|}
\hline \multirow{3}{*}{ Group } & & \multicolumn{3}{|l|}{ fasting } & \multicolumn{3}{|c|}{$1 \mathrm{~h}$ after oral glucose } \\
\hline & & \multirow[t]{2}{*}{ IRI } & \multicolumn{2}{|c|}{ C-peptide } & \multirow[t]{2}{*}{ IRI } & \multicolumn{2}{|c|}{ C-peptide } \\
\hline & & & M 1017 & M 1181 & & M 1017 & M 1181 \\
\hline \multirow[t]{2}{*}{15 normal subjects } & mean & 0.048 & 0.37 & 0.35 & 0.52 & 2.53 & 2.24 \\
\hline & $\mathrm{SD}$ & 0.033 & 0.071 & 0.09 & 0.29 & 0.70 & 0.71 \\
\hline \multirow{2}{*}{$\begin{array}{l}8 \text { maturity-onset } \\
\text { diabetics }\end{array}$} & mean & 0.11 & 0.86 & 0.74 & 0.49 & 2.49 & 2.34 \\
\hline & $\mathrm{SD}$ & 0.088 & 0.51 & 0.51 & 0.32 & 0.93 & 1.18 \\
\hline \multirow{2}{*}{$\begin{array}{l}10 \text { insulin- } \\
\text { dependent diabetics }\end{array}$} & mean & 0.063 & 0.37 & 0.21 & 0.105 & 0.49 & 0.42 \\
\hline & $\mathrm{SD}$ & 0.027 & 0.14 & 0.14 & 0.042 & 0.17 & 0.24 \\
\hline
\end{tabular}

all the insulin antibodies of guinea pig sera at neutral $\mathrm{pH}$. The elution of antibodies at low $\mathrm{pH}$ caused considerable losses - only $25-37 \%$ was recovered. It is not known whether the antibodies were destroyed at the low $\mathrm{pH}$ or remained bound to the S-I. This is being investigated using ${ }^{125} \mathrm{I}$-labelled antibodies. Surprisingly, only $50 \%$ of the immunoreactivity of the antibodies was lost in the coupling to Sepharose, so that the overall yield of S-AIS was about $15 \%$. The binding capacity of the S-AIS was the same towards proinsulin and IRI. S-AIS with a binding capacity of 1 $\mathrm{mU}$ was sufficient to remove $95 \%$ of IRI in $1 \mathrm{ml}$ volumes containing up to $10 \mathrm{ng}$ of either insulin or proinsulin (both labelled and unlabelled). Therefore, sera having IRI $>10 \mathrm{ng} / \mathrm{ml}$ should either be diluted before adding S-AIS or S-AIS should be added in higher amounts. Serum from insulin-treated patients which contains insulin antibodies should not be treated with S-AIS directly. In those patients who have some residual B-cell activity human proinsulin has been shown to be present, bound as it were to the endogenous insulin antibodies $[1,3]$, and therefore proinsulin will not be removed from their serum by S-AIS. The serum must be subjected to extraction [4] prior to treatment with S-AIS and determination of C-peptide.

\section{Sources of Error in the Determination of C-Peptide in Serum}

Synthetic C-peptide was used as the standard because no natural peptide was available. Pancreatic extracts containing approximately 2000 pmole of Cpeptide $/ \mathrm{ml}$ showed, however, a dilution pattern somewhat different to that of the synthetic standard. The pancreatic extracts probably contain a variety of
C-peptide fragments, which may be an explanation of the difference. Another possibility is that the synthetic standard is different from the natural C-peptide. A second batch of synthetic human C-peptide was prepared recently [11]; it deviates from the batch employed in this study and has shown considerable similarity to natural C-peptide. A comparative study of the synthetic connecting peptide and the natural Cpeptide [8], using antibodies against the connecting peptide $(\mathrm{C}$-peptide $=$ connecting peptide lacking two pairs of basic amino acids at each terminal), concludes that the two peptides have approximately the same degree of reactivity, through without showing the results. In another paper [17], synthetic C-peptide was reported to have $85-90 \%$ of the immunoreactivity of the natural C-peptide with an antiserum against natural C-peptide. Table 3 shows the dilutions of a series of samples with C-peptide levels higher than 1 pmole/ $\mathrm{ml}$. Dilution effects similar to the one observed in pancreatic extracts were observed in many samples. Again, the difference in reactivity could be due to the presence of degraded fragments of C-peptide, or it could represent a difference in the characteristics of the natural and the synthetic C-peptide.

Another source of error is the displacement of the tracer, which was first observed with sera from longterm insulin treated juvenile diabetics who had shown no C-peptide or IRI response to i.v. glucagon. The displacement varies from one antiserum to another $(0-0.16 \mathrm{nM})$ and the fact that zero values were consistently found with $\mathrm{M} 1181$ shows that this phenomenon is most likely due to substances other than C-peptide and proinsulin. This is supported by the finding of a weak displacement with pure human IgG (own observation). Moreover, determination of C-peptide in sera devoid of insulin antibodies with M 1017 (up to $0.07 \mathrm{nM}$ in the "zero serum") and M 1181 revealed 
slightly lower values with M 1181 (Table 4). During suppression of endogenous insulin by fish insulin in normal persons [15] it was observed that $\mathrm{C}$-peptide dropped in some cases to undetectable values after 3-4 hours when measured with M 1181, whereas the values recorded with M 1017 were approximately $0.07 \mathrm{nM}$ in the same samples [7]. All the aforementioned findings lend support to the hypothesis that some antisera to human C-peptide are capable of reacting, to varying degrees, with substances in serum that are different from C-peptide, proinsulin and fragments thereof. It is interesting to note that the SD of repeated determinations of $\mathrm{C}$-peptide in different assays in the same control sera was about 4 times less with M 1181 than with M 1017 (see page 8). Although M 1017 and M 1181 yield practically identical standard curves, M 1181 was chosen for the determination of C-peptide due to its "zero value" and its low assay-to-assay variation.

The mean C-peptide concentrations registered in 15 normal persons using M 1181 - basal and $1 \mathrm{~h}$ after oral glucose $(1.75 \mathrm{~g} / \mathrm{kg})$ - were $0.35 \pm 0.1 \mathrm{nM}(=1.1$ $\pm 0.3 \mathrm{ng} / \mathrm{ml})$ and $2.24 \pm 0.71 \mathrm{nM}(=6.7 \pm 2.1$ $\mathrm{ng} / \mathrm{ml}$ ). The basal value was slightly lower than the value of $1.3 \pm 0.3 \mathrm{ng} / \mathrm{ml}$ reported by [2] and slightly higher than $0.88 \pm 0.21$ as reported by [8]. The recordings after glucose show greater variations, from $6.7 \pm 2.1 \mathrm{ng} / \mathrm{ml}$ found here to $4.4 \pm 0.8$ [2] and $5.1 \pm$ $0.7 \mathrm{ng} / \mathrm{ml}[8]$. Differences in the standards used are a likely explanation, though the fact that serum was added to the standards in [2] and [8] may have reduced the values recorded in these assays. This will show up most clearly in samples with high C-peptide concentrations, which have to be diluted.

\section{Methodology in General}

As C-peptide has no biological activity, the radioimmunoassay is the only analytical technique available for its determination. In spite of the interest currently focussed on C-peptide, only three research groups have succeeded in establishing an assay $[2,6$, 8] due to the numerous problems it presents, such as: preparation of C-peptide and ${ }^{125} \mathrm{I}$-Tyr-C-peptide, production of antibodies and separation of $\mathrm{C}$-peptide from proinsulin-containing substances. The first assay to be described [14] used antibodies against natural C-peptide coupled to albumin which had low capacity (final dilution 1:500) and low affinity (detection limit: $0.75 \mathrm{ng}$ total added). In addition to this, separation of C-peptide from PLI by gel filtration of serum extracts probably resulted in heavy losses of C-peptide, for C-peptide and insulin were found to be present in peripheral blood in equimolar amounts.
Later, the gel filtration procedure was left out [2] and total C-peptide immunoreactivity (CPR) was measured in unextracted serum. In this assay, C-peptide was found to be $1.3 \pm 0.3 \mathrm{ng} / \mathrm{ml}$ in fasting normal persons, i.e., a value much higher than IRI.

In an assay based exclusively on synthetic human connecting peptide [8], use was made of antibodies in a final dilution of $1: 17000$ and a detection limit of 0.1 ng per tube. No separation was performed, so that the assay was in regard of total CPR.

This paper reports on the production of antibodies using human b-component, which could be used in a final dilution of $1: 2100-1: 3000$, with the best serum giving a detection limit of 0.003 pmole in 100 $\mu \mathrm{l}$. This is a significant feature because many diabetic patients have particularly low C-peptide levels.

The separation technique reported here is very quick and features advantages over the techniques reported earlier [6], where the PLI + IRI was bound to insulin antibodies and removed by ethanol precipitation, necessitating evaporation before analysis. The use of Sepharose-coupled antibodies (S-AIS) for binding of PLI + IRI implies that, following centrifugation, C-peptide can be determined direct in the supernatant. Although total CPR will be very close to $\mathrm{C}$-peptide values in many normal samples, the determination of C-peptide should be preferable to determining total CPR since this assay will be applied primarily to diabetic sera, which - in the case of maturity-onset type diabetics - have been shown to have elevated proinsulin [1]. The same applies to insulinoma patients. Furthermore, as long as we do not know the ratio of proinsulin to $\mathrm{C}$-peptide in, e.g., juvenile diabetics, and being, moreover, cognizant of the fact that proinsulin and $\mathrm{C}$-peptide react differently with the antibodies used so far $[2,6,8]$, it is preferable to remove PLI before estimating C-peptide.

In insulin treated patients who have antibodies to insulin it is necessary to include an acid extraction of the serum before adding S-AIS and determining C-peptide.

Finally, it should be stressed that there still are some sources of error in the C-peptide assay that remain to be solved. First of all, there is the problem of identity of synthetic and natural C-peptides and of characterization of the circulating C-peptide, which could be a fragment of the intact molecule, for instance fragment 1-24, which was found in pancreatic extracts [6].

Acknowledgements. The excellent technical assistance of Mrs. Lisbet Pedersen and Miss Marianne Knudsen is gratefully acknowledged. 


\section{References}

1. Block, M. B., Mako, M., Steiner, D. F., Rubenstein, A. H.: Elevated circulating proinsulin levels in insulin-requiring diabetic patients. J. Lab. clin. Med. 78, 811-812 (1971)

2. Block, M. B., Mako, M. E., Steiner, D. F., Rubenstein, A. H.: Circulating C-peptide immunoreactivity. Studies in normals and diabetic patients. Diabetes 21, 1013-1026 (1972)

3. Fink, G., Cresto, J. C., Gutman, R. A., Lavine, R. L., Rubenstein, A. H., Recant, L.: Plasma proinsulin-like material in insulin treated diabetics. Horm. Metab. Res. 6, 439-443 (1974)

4. Heding, L. G.: Determination of total serum insulin (IRI) in insulin treated diabetic patients. Diabetologia 8, 260-266 (1972)

5. Heding, L. G.: Radioimmunological determination of pancreatic and gut glucagon in plasma. Diabetologia 7, 10-19 (1972)

6. Heding, L. G., Larsen, U. D., Markussen, J., Jørgensen, K. H., Hallund, O.: Radioimmunoassays for human, pork and ox C-peptides and related substances. Horm. Metab. Res. Suppl. Vol. 5, 40-44 (1974)

7. Heding, L. G., Turner, R. C., Harris, E.: C-peptide, proinsulin and insulin responses to fish-insulin induced hypoglycaemia in the diagnosis of insulinomas. Diabetes 24 (Suppl. 2), 412 (1975)

8. Kaneko, T., Oka, H., Munemura, M., Oda, T., Yamashita, K., Suzuki, S., Yanaihara, N., Hashimoto, T., Yanaihara, C.: Radioimmunoassay of human proinsulin C-peptide using synthetic human connecting peptide. Endocr. jap. 21, 141-145 (1974)

9. Markussen, J., Sundby, F., Smyth, D. G., Ko, A.: Preparation of human C-peptide. Horm. Metab. Res. 3, 229-232 (1971)

10. Markussen, J., Heding, L. G., Jørgensen, K. H., Sundby, F.: Proinsulin, insulin and C-peptide. Horm. Metab. Res. Suppl. Series No. 3, 33-35 (1971)
11. Naithani, V. K., Dechesne, M., Markussen, J., Heding, L. G., Larsen, U. D.: Studies on Polypeptides, VI ${ }^{1}$, synthesis, circular dichroism and immunological studies of tyrosyl human C-peptide. Hoppe-Seylers Z. physiol. Chem. 356, 1305-1312 (1975)

12. Naithani, V. K., Dechesne, M., Markussen, J., Heding L. G.: Studies on polypeptides, $\mathrm{V}^{1}$. Improved synthesis of human proinsulin C-peptide and its benzyloxy-carbonyl derivative. Circular dichroism and immunological studies of human C-peptide. Hoppe-Seylers Z. physiol. Chem. 356, 997-1010 (1975)

13. Östman, J., Arner, P., Groth, C.-G., Heding, L., Jorfeldt, L., Lundgren, G.: Pancreastransplantation vid diabetes mellitus: Studier av pankreas endokrina funktion och intermedicinska synspunkter. (paper in preparation)

14. Rubenstein, A. H., Block, M. B., Starr, J., Melani, F., Steiner, D. F.: Proinsulin and C-peptide in blood. Diabetes 21 (Suppl. 2), 661-672 (1972)

15. Turner, R. C., Harris, E.: Diagnosis of insulinomas by suppression tests. Lancet 1974 II, 188-190

16. Schlichtkrull, J.: Proinsuline et substances apparantées. Path. et Biol. 19, 885-892 (1971)

17. Yanaihara, N., Hashimoto, T., Yanaihara, C., Sakagami, M., Steiner, D. F., Rubenstein, A. H.: Synthesis of human connecting peptide derivatives and their immunological properties. Biochem. biophys. Res. Commun. 59, 1124-1130 (1974)

Dr. L. G. Heding

Novo Research Institute

Novo Allé

DK-2880 Bagsvaerd

Denmark 